\title{
Madeleine Lassère, Le Portrait double. Julie Candeille et Girodet, roman historique
}

\section{Lise Sabourin}

\section{(2) OpenEdition}

10 Journals

\section{Édition électronique}

URL : http://journals.openedition.org/studifrancesi/9253

DOI : 10.4000/studifrancesi.9253

ISSN : 2421-5856

Éditeur

Rosenberg \& Sellier

\section{Édition imprimée}

Date de publication : 1 juin 2008

Pagination : 200

ISSN : 0039-2944

\section{Référence électronique}

Lise Sabourin, « Madeleine Lassère, Le Portrait double. Julie Candeille et Girodet, roman historique », Studi Francesi [En ligne], 154 (LII | I) | 2008, mis en ligne le 30 novembre 2015, consulté le 13 janvier 2021. URL : http://journals.openedition.org/studifrancesi/9253; DOI : https://doi.org/10.4000/studifrancesi. 9253

Ce document a été généré automatiquement le 13 janvier 2021.

\section{(c) (†) $\ominus$}

Studi Francesi è distribuita con Licenza Creative Commons Attribuzione - Non commerciale - Non opere derivate 4.0 Internazionale. 


\section{Madeleine Lassère, Le Portrait double. Julie Candeille et Girodet, roman historique}

Lise Sabourin 


\section{RÉFÉRENCE}

MADELEINE LASSÈRE, Le Portrait double. Julie Candeille et Girodet, roman historique, Paris,

L'Harmattan, 2005, pp. 288.

1 Pour retracer la relation orageuse qui unit, vingt ans durant, Girodet et celle qui se présentait comme son «épouse de cœur et de travaux», Julie Candeille (1767-1834), Madeleine Lassère a choisi la forme romancée d'un journal prêté à cette femme de lettres aujourd'hui oubliée. La «sulfureuse Julie» (cette créole blanche eut de nombreux amants et trois maris) a laissé, outre quelques ouvrages à contenu autobiographique notamment une notice manuscrite sur sa liaison avec le peintre impérial- des romances et poèmes que le présent livre publie (pp. 253-271). Ce «double portrait» donne envie de lire les trois cents lettres adressées par l'égérie et la copie d'une trentaine de réponses de son correspondant, de 1807 à 1824, conservées au musée Girodet de Montargis, que la Société archéologique et historique de l'Orléanais a entrepris de publier.

2 Même si M. Lassère reconnaît avoir dû combler par le vraisemblable les lacunes laissées par l'inachèvement des Mémoires entrepris à la fin de sa vie par l'honorable Mme Périé aussi bien que par l'absence de documents sur la période 1802-1806, ce pseudo-journal, qui recourt à nombre de citations intégrées et se munit de notes en fin de chapitres, a l'avantage de donner à sentir la condition réservée à cette actrice et musicienne auprès du peintre célèbre dont les toiles s'égrènent au fil de leurs jours amoureux (comme l'atteste leur index, pp.277, outre celui des personnages cités, notamment contemporains, pp. 278-283). 